\title{
Edukasi dan Workshop Pemanfaatan Herbal Untuk Kanker Serviks Pada Ibu-Ibu PKK di Desa Laban, Mojolaban, Sukoharjo
}

\section{Education and Workshop on The Use of Herbs Medicine for Cervical Cancer in Family Empowerment and Welfare (PKK) Laban, Mojobalan, Sukoharjo}

\author{
Novena Yety Lindawati ${ }^{1}$, Lusia Murtisiwi ${ }^{2}$, Tesia Aisyah Rahmania ${ }^{3}$ \\ 1,2,3 Sekolah Tinggi Ilmu Kesehatan Nasional, Surakarta, Indonesia \\ 1novenayl@yahoo.com, ${ }^{2}$ lusia@ericdesign-jogja.com, ${ }^{3}$ tesiaaisyah4@gmail.com
}

Riwayat Artikel: Dikirim 20 November 2019; Diterima 15 Mei 2020; Diterbitkan 20 Mei 2020

\begin{abstract}
Abstrak
Kejadian kanker serviks atau yang dikenal dengan kanker leher rahim menjadi salah satu penyebab kematian pada wanita. Menurut Data WHO (Tahun 2014) lebih dari 92 ribu kasus kematian wanita Indonesia disebabkan oleh penyakit kanker di mana 10\%nya disebabkan oleh kanker serviks. Hal ini melandasi pelaksanaan kegiatan Pengabdian Masyarakat Program Studi S1 Farmasi STIKES NASIONAL bersama Himpunan Mahasiswa Farmasi (HIMFARNAS) untuk memberikan "Edukasi dan Workshop Pemanfaatan Herbal Untuk Kanker Serviks pada Ibu-Ibu PKK Laban, Mojolaban, Sukoharjo". Kegiatan ini diikuti oleh 65 peserta. Antusiasme peserta sangat terlihat selama kegiatan berlangsung. Kegiatan ini dilaksanakan dalam bentuk promotif, preventif, kuratif, dan rehabilitatif melalui edukasi dan workshop pemanfaatan herbal untuk kanker cerviks, evaluasi kegiatan dilakukan dengan memberikan pretest dan postest. Edukasi pertama oleh Lusia Murtisiwi yang menyampaikan materi tentang penyakit kanker serviks, penyebabnya, faktor risikonya, gejala-gejala yang perlu diwaspadai, serta penanganan kanker serviks secara medis. Edukasi tentang bahan alam di sekitar yang dapat digunakan untuk terapi alternatif pendamping pengobatan kanker serviks oleh Novena Yety Lindawati. Kegiatan workshop dipandu oleh HIMFARNAS (Himpunan Mahasiswa Farmasi Program Studi S1 Farmasi STIKES Nasional) yang melatih peserta dalam pembuatan dan packaging produk "ROMANSA". Produk ini terdiri dari tanaman berkhasiat antikanker yang meliputi Bunga Rosella dan Daun Sirsat serta Madu sebagai pemanis. Produk minuman ini bisa konsumsi sendiri atau dijual sebagai usaha industri rumah tangga ibu-ibu PKK. Hasil kegiatan ini menunjukkan adanya peningkatan pengetahuan ibu-ibu PKK Desa laban tentang upaya preventif, deteksi dini kanker serviks, dan terapi pendukung penanganan kanker serviks secara alami, ditunjukkan dengan peningkatan nilai postest, dari nilai pretest rata-rata 60,8 menjadi 96,2. Selain itu hasil evaluasi kepuasan program pengabdian masyarakat secara keseluruhan baik sekali.
\end{abstract}

Kata kunci: Edukasi dan Workshop, Kanker serviks, Produk "ROMANSA"

\begin{abstract}
Cervical cancer is one of the causes of death in women. According to WHO data (in 2014) more than 93 thousand cases of death of Indonesian women caused by cancer in which $10 \%$ is caused by cervical cancer. This underlies the implementation of Community Service of Program Study S1 Pharmacy STIKES NASIONAL with Himpunan Mahasiswa Farmasi STIKES Nasional (HIMFARNAS) to provide "Education and Workshop on The Use of Herbs Medicine for Cervical cancer in Family Empowerment and Walfare (PKK) Laban, Mojobalan, Sukobarjo". This activity was attended by 65 participants. The participant was very enthusiasm during the activity. This activity is carried out in the form of promotive, preventive, curative, and rehabilitative through education and workchops on the use of herbs for cervical cancer. Evaluation of activities is done by giving a pretest and posttest. The first education was presented by Lusia Murtisiwi who delivered material about its causes, risk factors and symptoms cervical cancer that need to be concern as well as medical treatment. Education about surrounding natural materials that can be used for alternative therapies to accompany cervical cancer treatment presented by Novena Yety Lindawati. The workshop was guided by HIMF ARNAS who trained participants in the manufacturing and packaging of "ROMANSA" products. This product consists of anticancer effect which include rosella and sirsat leaves and honey as the sweetener. These beverage products can be consumed by themselves or sold as a home industry business for Family Empowerment and Walfare (PKK). The results of this activity showed an increase in knowledge of the Family Empowerment and W alfare (PKK) participants about preventive measures, early detection of cervival cancer, and supporting therapies for handling cervical cancer naturally, as indicated by an increase in posttest values from average 60.8 to 96.2. In addition, the results of evaluations of overall community service satisfaction programs are very good
\end{abstract}

Keywords: Education and Workshop, Cervical cancer, Romance Product 


\section{PENDAHULUAN}

Pada tahun 2013 diketahui bahwa penyakit kanker serviks merupakan penyakit kanker dengan prevalensi tertinggi di Indonesia, yaitu sebesar $0,8 \%$. Berdasarkan estimasi jumlah penderita kanker serviks terbanyak terdapat pada Provinsi Jawa Timur dan Provinsi Jawa Tengah. Faktor perilaku dan pola makan berperan penting terhadap timbulnya kanker. Kelompok umur 25-34 tahun, 35-44 tahun, dan 45-54 tahun merupakan kelompok umur dengan prevalensi kanker yang cukup tinggi (Kemenkes RI, 2015).

Kanker leher rahim atau lebih dikenal dengan istilah kanker serviks adalah kanker yang terjadi pada serviks uterus, suatu daerah pada organ reproduksi wanita yang merupakan pintu masuk ke arah rahim yang terletak antara rahim (uterus) dengan liang senggama (vagina). Kanker ini biasanya terjadi pada wanita yang telah berumur, tetapi bukti statistik menunjukkan wanita berumur 20-30 tahun dapat terserang kanker serviks (Diananda, 2009). Kanker serviks adalah tumor ganas yang tumbuh di dalam leher rahim/serviks (bagian terendah dari rahim yang menempel pada puncak vagina. Kanker serviks merupakan suatu penyakit yang disebabkan oleh infeksi virus buman papillomavirus. Infeksi buman papilloma virus dapat menyerang wanita maupun pria (American Cancer Society, 2010).

Kanker serviks merupakan kanker keempat yang paling sering diderita oleh wanita dengan perkiraan 570.000 kasus baru pada tahun 2018 yang mewakili 6,6\% dari semua kanker wanita. Sekitar $90 \%$ kematian akibat kanker serviks terjadi di negaranegara berpenghasilan rendah dan menengah. Tingkat kematian yang tinggi dari kanker serviks secara global dapat dikurangi melalui pendekatan komprehensif yang mencakup pencegahan, diagnosis dini, skrining yang efektif dan program pengobatan. Saat ini ada vaksin yang melindungi terhadap jenis virus human papilloma yang disebabkan oleh kanker dan dapat secara signifikan mengurangi risiko kanker serviks (WHO, 2018).

Desa Laban secara geografis termasuk dalam wilayah Kecamatan Mojolaban, Kabupaten Sukoharjo. Wilayah Desa Laban di sebelah utara berbatasan dengan Desa Plumbon, sebelah timur berbatasan dengan Desa Wirun, sebelah selatan berbatasan dengan Desa Tegalmade, sedangkan sebelah barat berbatasan dengan Sungai Bengawan Solo. Desa Laban memiliki luas wilayah 225,44 hektar dengan area pertanian yang lebih luas daripada area pemukiman, sehingga Desa Laban mempunyai potensi di bidang pertanian.

Mata pencaharian penduduk Desa Laban yang terbanyak adalah petani. Selain petani, mata pencaharian lainnya adalah buruh, karyawan, pemulung, dan lain-lain. Secara ekonomi, masyarakat Desa Laban masih relatif menengah ke bawah. Latar belakang pendidikan masyarakat Desa Laban masih relatif rendah di mana mayoritas merupakan lulusan Sekolah Dasar (SD)-Sekolah Menengah Atas (SMA). Masyarakat dengan latar belakang lulusan Diploma 3 (D3)-Strata 2 (S2) masih jarang.

Kondisi kesehatan masyarakat Desa Laban masih perlu terus ditingkatkan, terutama kesehatan wanita usia subur. Berdasarkan wawancara dengan Petugas Penyuluh Kesehatan Desa, salah satu masalah kesehatan yang muncul pada ibuibu di Desa Laban adalah adanya kejadian ibu-ibu yang menderita kanker serviks, sehingga diperlukan upaya pencegahan dan promosi kesehatan yang tepat untuk mengurangi kejadian kanker serviks. Tanaman berkhasiat antioksidan yang bermanfaat mencegah kanker banyak tumbuh di Desa Laban ini.

Hal ini mendasari dilakukannya kegiatan program pengabdian kepada masyarakat dengan tema "Edukasi dan Workshop Pemanfaatan Herbal untuk Kanker Serviks pada Ibu-ibu PKK di Desa Laban, Kecamatan Mojolaban, Kabupaten Sukoharjo". Kegiatan pengabdian masyarakat ini dilaksanakan dalam bentuk 
promotif, preventif, kuratif, dan rehabilitatif dengan memberikan penyuluhan tentang penyakit kanker serviks dan penanganannya secara alami baik dengan bahan alam

\section{METODE}

\section{Tahap persiapan}

Tahap persiapan diawali dengan pendekatan dengan warga masyarakat Desa Laban, khususnya ibu-ibu PKK. Pendekatan dengan warga dimulai melalui koordinasi dengan pengurus PKK Desa untuk bersama-sama menggali permasalahan yang ada di masyarakat dan rencana solusi yang dapat diterapkan. Setelah berkoordinasi dengan pengurus PKK, selanjutnya dilakukan sosialisasi pada masyarakat, khususnya ibu-ibu PKK melalui pertemuan rutin bulanan PKK.

\section{Tahap pelaksanaan}

a. Edukasi tentang kanker serviks (penyuluhan)

Pada tahap ini dilakukan penyuluhan tentang kanker serviks, penyebab kanker serviks, gejala kanker serviks yang perlu diwaspadai, deteksi dini serta penanganannya secara medis.

\section{b. Edukasi tentang tanaman berpotensi antikanker (penyuluhan)}

Pada tahap ini dilakukan penyuluhan tentang tanaman yang berpotensi antikanker. Pada tahap ini juga diberikan edukasi tentang cara pembuatan ramuan herbal dari berbagai tanaman berpotensi antikanker.

\section{c. Workshop pembuatan produk minuman herbal "Romansa"}

Pada tahap ini dilakukan workshop pembuatan produk minuman herbal yang dinamai "Romansa". Produk ini terdiri dari dari daun sirsak (10 lembar) dan bunga rosela (7 bunga) direbus dengan $300 \mathrm{ml}$ air hingga setengahnya, ditambahkan madu maupun pola gaya hidup sehingga dapat meningkatkan kesehatan dan kualitas hidup masyarakat Desa Laban, Kecamatan Mojolaban, Kabupaten Sukoharjo. sebagi pemanis dan dikemas dalam botol tertutup rapat dan berlabel.

\section{d. Tahap monitoring dan evaluasi}

Monitoring dan evaluasi keberhasilan program pengabdian masyarakat ini dilakukan dengan memberikan soal pretest sebelum penyuluhan dan postest sesudah penyuluhan pada peserta ibu-ibu PKK.

Evaluasi kegiatan ini juga dilakukan dengan memberikan angket/ kuesioner kepuasan pelanggan kegiatan pengabdian kepada masyarakat pada peserta untuk diisi.

Keberhasilan kegiatan workshop dilihat dari peningkatan keterampilan peserta yang semula belum bisa membuat produk minuman herbal menjadi bisa membuat produk minuman herbal tersebut sesuai yang diajarkan pemateri.

Luaran workshop ini berupa produk minuman herbal segar yang diberi nama "ROMANSA" (rosella, madu, daun sirsak).

\section{HASIL DAN PEMBAHASAN}

Kejadian kanker serviks atau yang dikenal dengan kanker leher rahim menjadi salah satu penyebab kematian pada wanita. Menurut Data WHO (Tahun 2014) lebih dari 92 ribu kasus kematian wanita Indonesia disebabkan oleh penyakit kanker dimana 10\%nya disebabkan oleh kanker serviks. Hal ini yang melandasi pelaksanaan kegiatan Program Pengabdian Masyarakat Program Studi S1 Farmasi STIKES NASIONAL bersama Himpunan Mahasiswa Farmasi (HIMFARNAS) untuk memberikan Edukasi tentang Kanker Serviks dan Penanganannya secara alami pada ibu-ibu PKK Desa Laban, Kecamatan Mojolaban, Kabupaten Sukoharjo. Kegiatan 
ini diikuti oleh 65 peserta termasuk Ibu Sri Mariani, istri dari Kepala Desa Laban yang baru terpilih.

\section{A. Edukasi tentang Kanker Serviks dan Terapi Pendukung Alami}

Kegiatan edukasi melalui
penyuluhan tentang kanker serviks didahului dengan pemberian soal pretest untuk mengukur pengetahuan peserta sebelum diberikan edukasi. Antusiasme peserta sangat terlihat selama kegiatan berlangsung. Dalam edukasi kanker serviks oleh Lusia Murtisiwi; Human Papiloma Virus (HPV) 16 dan 18 merupakan penyebab dari kanker serviks. Gejala-gejala kanker serviks yang harus diwaspadai seperti keluar darah dari vagina secara tiba-tiba, sakit pada panggul, keputihan tidak normal, mengalami perubahan jadwal $\mathrm{BAB}$ serta mengalami kelelahan yang berlebihan. Beliau juga menyampaikan faktor-faktor yang meningkatakan risiko terjadinya kanker serviks antara lain berganti-ganti pasangan (risiko terinfeksi HPV), memiliki kekebalan tubuh yang lemah, merokok aktif maupun pasif (menghirup asap rokok dari lingkungan sekitar), dan adanya riwayat keluarga yang memiliki kanker serviks. Penanganan kanker serviks secara medis melalui operasi, kemoterapi dan radioterapi.

Selain penanganan secara medis, banyak bahan alam di sekitar lingkungan dapat digunakan untuk terapi alternatif pendamping pengobatan kanker serviks seperti yang disampaikan oleh Novena Yety Lindawati. Pada sesi ini juga disampaikan beberapa bahan alam seperti rebusan sarang semut (Mymrmecodia pendans) dari Papua terbukti mengandung senyawa polifenol, antioksidan, dan antikanker yang mampu menghambat persebaran dari kanker serviks. Kunir putih (Curcuma zeodaria) kaya akan antioksidan dan minyak atsiri sebagai anti kanker. Kandungan Ribozome Inactivating Protein memiliki bersifat sitotoksik pada sel kanker. Hati-hati dalam pemilihan rimpang kunir putih, karena berwarna putih seperti kunir mangga, dianjurkan untuk memilih kunir putih dengan ciri rimpang bergerombol bulat-bulat kecil pada emponnya, warna rimpang putih dan tidak beraroma mangga. Cara konsumsi mudah perasan dari 10 gram kunir dicampur madu dan diminum 2 kali dalam sehari. Ibu Novena juga menyampaikan adanya sup dari 5 sayur untuk pengobatan kanker, dalam hal ini 5 sayuran yang berasal dari dalam negeri yang jika dikombinasi bisa digunakan untuk terapi kanker serviks yaitu ramuan daun belimbing, daun pepaya, daun cermai muda, daun bayam merah dan wortel yang diblender semua hingga lembut lalu ditambahankan air hangat kedalamnya dan diperas. Minum ramuan ini bersama dengan madu sehari sekali. Catharantus roseus yang dikenal dengan nama tapak dara, daunnya mengandung vinkristin dan vinblastin yang aktif menghambat perkembangan kanker tanpa merusak sel normal lainnya. Sebanyak 22 lembar daun tapak dara direbus bersama dengan kayu pulosari serta buah adas dalam $300 \mathrm{ml}$ air hingga setengahnya, ramuan dikonsumsi rutin dalam kurun waktu 1 bulan. Madu dapat digunakan sebagai pemanis jika terasa pahit. Penggunaan daun tapak dara ini harus sangat hati-hati.

Antusiasme dari peserta terlihat dari banyaknya pertanyaan dari peserta dalam diskusi saat penyuluhan (gambar 1). Pertanyaan dari peserta di antaranya adalah: "mengapa seorang ibu yang sholehah dengan suami yang senang melakukan seks bebas dapat menderita kanker serviks?". Narasumber memberikan jawaban atas pertanyaan ini: "penyebab kanker serviks adalah buman papilloma virus (HPV) tipe 16 dan 18. Virus ini dapat menular juga pada laki-laki, sehingga jika suaminya tertular virus $\mathrm{HPV}$ ini, maka istrinya juga berisiko tertular virus tersebut dari suaminya saat berhubungan suami istri. Selain itu juga masih ada beberapa faktor risiko lain seperti nutrisi yang kurang seimbang, stress berlebihan, sering terpapar rokok (misalnya perokok pasif), serta kurang higienisnya organ genitalia". 


\section{B. Workshop Pembuatan Produk Minuman Herbal}

Pemanfaatan bahan alam sekitar juga diterapkan dalam acara ini. Mahasiswa yang tergabung dalam HIMFARNAS memandu pemuatan "ROMANSA" minuman segar untuk terapi pendukung kanker yang terbuat dari daun sirsak (10 lembar) dan rosela (7 bunga) direbus dengan $300 \mathrm{ml}$ air hingga setengahnya, ditambahkan madu sebagi pemanis dan dikemas dalam botol tertutup rapat, Minuman ini bisa konsumsi sendiri atau dijual sebagai usaha industri rumah tangga ibu-ibu PKK. Daun sirsak mengandung acetogenin yang dapat manghambat sel kanker. Bunga rosela kaya akan antosianin dan antioksidan mampu menghambat sel kanker. Edukasi ini memberikan wawasan dan ilmu pengetahuan serta keterampilan Ibu-Ibu PKK, Desa Laban, Kecamatan Mojolaban, Kabupaten Sukoharjo tentang kanker serviks dan bahan-bahan alami antikanker. Proses workshop pembuatan produk minuman herbal dapat dilihat pada gambar 2.

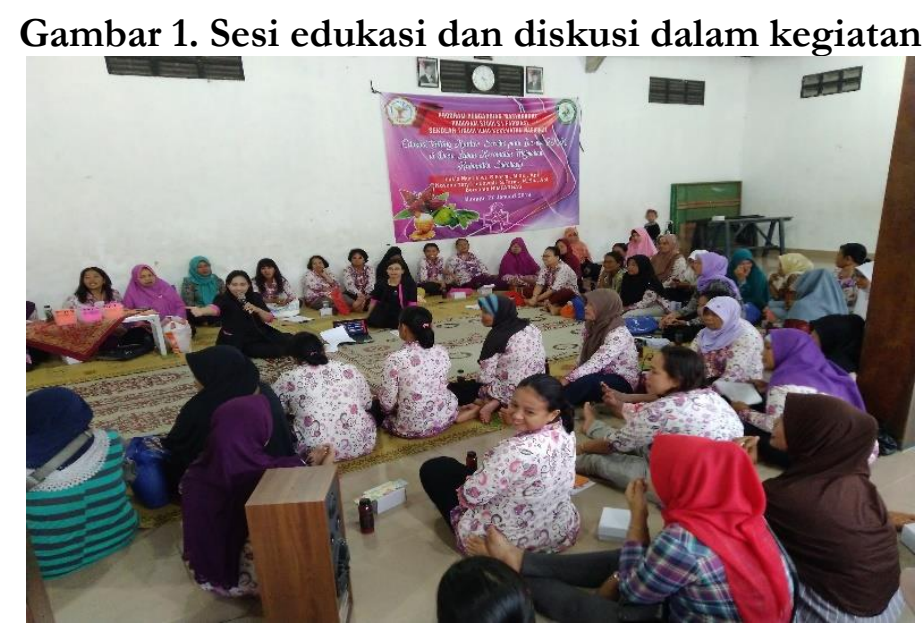

Sumber: Dokumentasi Pribadi

\section{Gambar 2. Proses workshop pembuatan produk minuman herbal}

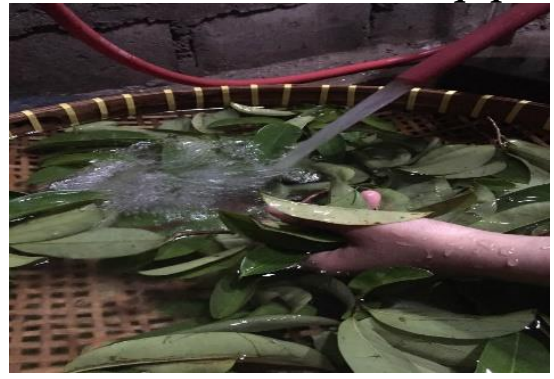

(1)

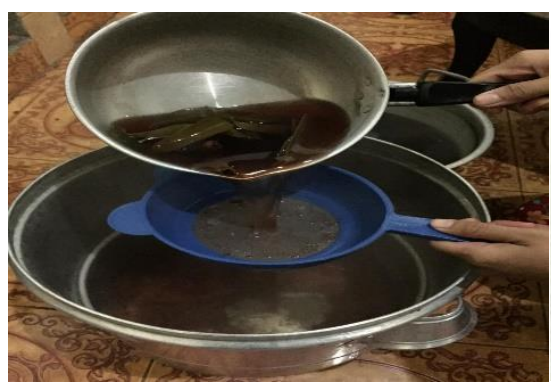

(3)

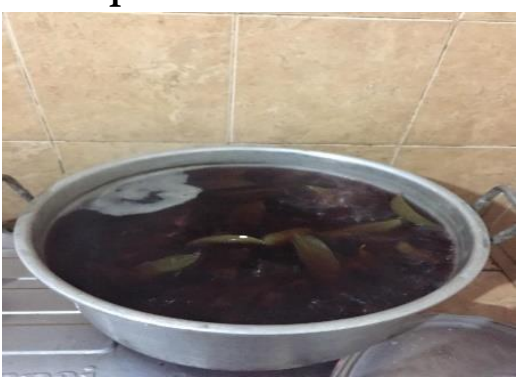

(2)

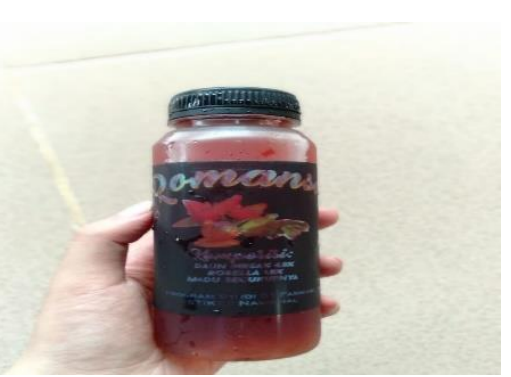

(4) 


\section{Evaluasi Kegiatan}

Kegiatan program pengabdian masyarakat ini diakhiri posttest dengan pertanyaan yang sama dengan pertanyaan pada pretest. Hasil posttest ini menujukkan adanya peningkatan pemahaman peserta tentang kanker serviks, penyebab kanker serviks, faktor risiko kanker serviks dan penanganannya serta tentang tanaman berpotensi antikanker menjadi lebih baik setelah kegiatan edukasi. Pengetahuan peserta tentang pengertian kanker serviks meningkat dari semula pada pretest $86 \%$ menjadi 100\% pada hasil posttest (gambar 3). Hal ini menunjukkan adanya peningkatan pengetahuan Ibu-ibu PKK di Desa laban tentang pengertian kanker serviks.

Gambar 3. Persentase hasil pretest dan posttest nomor 1 tentang pengertian kanker serviks

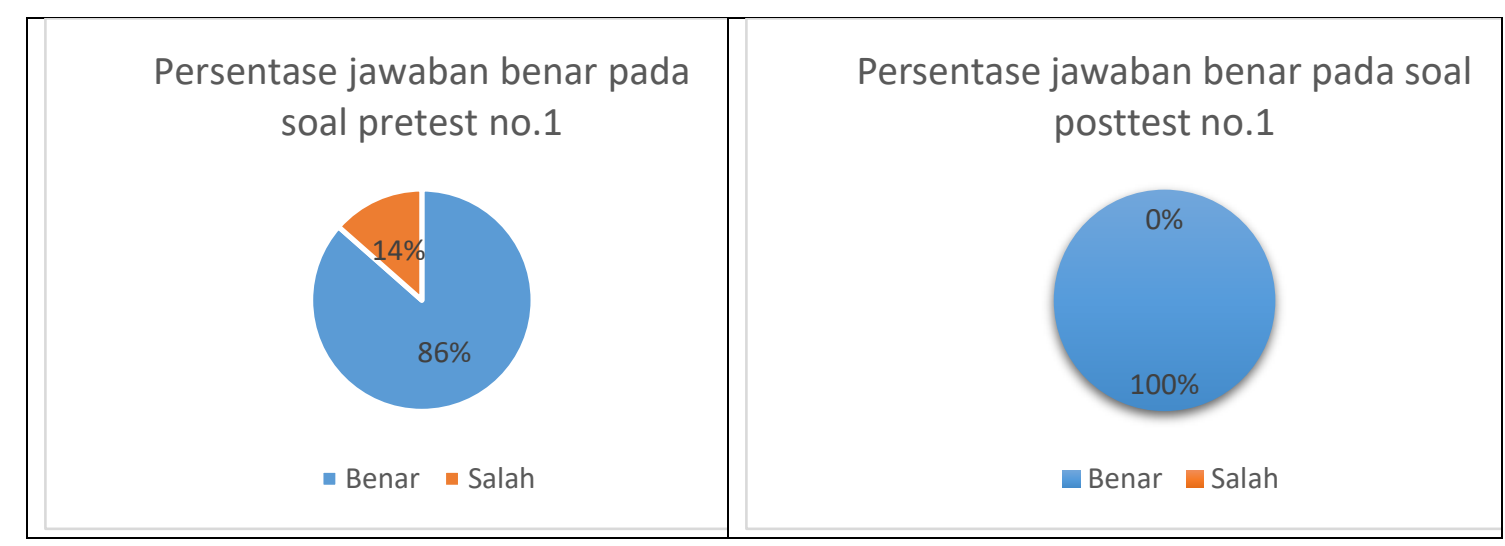

Hasil nilai pretest peserta pada pertanyaan nomor 2 tentang penyebab kanker serviks sebesar 69\% benar (gambar 4). Hasil nilai posttest peserta pada pertanyaan nomor 2 menjadi 98\% (gambar 4). Hal ini

menunjukkan adanya peningkatan pengetahuan peserta penyuluhan tentang penyebab kanker serviks setelah diberikan materi penyuluhan

Gambar 4. Persentase hasil pretest dan postest nomor 2 tentang penyebab kanker serviks

\begin{tabular}{|l|c|}
\hline $\begin{array}{c}\text { Persentase jawaban benar pada } \\
\text { soal pretest no.2 }\end{array}$ & $\begin{array}{c}\text { Persentase jawaban benar pada soal } \\
\text { posttest no.2 }\end{array}$ \\
\hline - Benar $=$ Salah & \\
\hline
\end{tabular}


Hasil nilai pretest peserta pada pertanyaan nomor 3 tentang faktor risiko kanker serviks masih rendah yaitu sebesar $48 \%$ (gambar 5). Setelah dilakukan penyuluhan, pengetahuan peserta tentang faktor resiko kanker serviks meningkat. Hal ini ditunjukkan dengan adanya peningkatan nilai peserta pada soal posttest nomor 3 yaitu menjadi $88 \%$ (gambar 5).

Gambar 5. Persentase hasil pretest dan postest nomor 3 tentang faktor resiko terjadinya kanker serviks

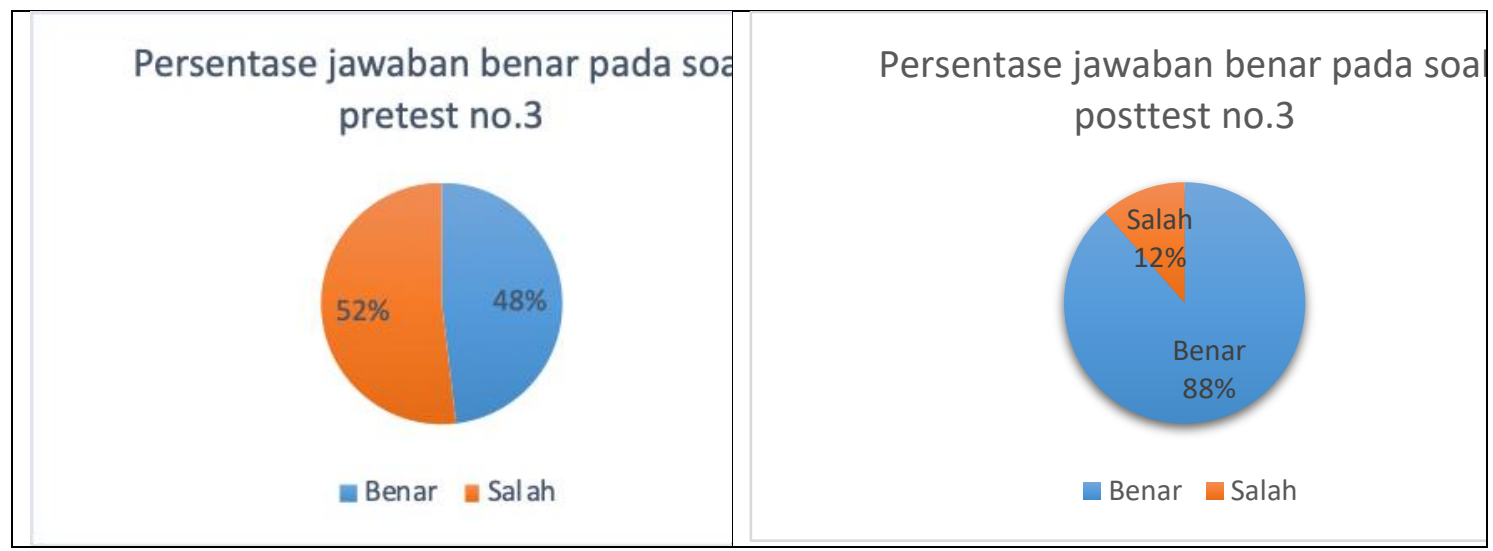

Pengetahuan peserta tentang penanganan kanker serviks sebelum dilakukan penyuluhan diukur pada soal pretest nomor 4. Hasil nilai pretest peserta pada pertanyaan nomor 4 tentang penanganan kanker serviks masih rendah yaitu sebesar 48\% (gambar 6). Setelah dilakukan penyuluhan, pengetahuan peserta tentang penanganan kanker serviks meningkat. Hal ini ditunjukkan dengan adanya peningkatan nilai peserta pada soal posttest nomor 4 yaitu menjadi 94\% (gambar 6).

Gambar 6. Persentase hasil pretest dan postest nomor 4 tentang penanganan kanker serviks

\begin{tabular}{|l|c|}
\hline $\begin{array}{c}\text { Persentase jawaban benar pada soal } \\
\text { pretest no.4 }\end{array}$ & $\begin{array}{c}\text { Persentase jawaban benar pada } \\
\text { soal posttest no.4 }\end{array}$ \\
\hline $52 \%$ & \\
\hline Benar $\square$ Salah & Benar $\square$ Sal ah \\
\hline
\end{tabular}

Pengetahuan peserta tentang tanaman berpotensi antikanker yang dapat digunakan sebagai alternatif pendukung terapi kanker serviks sebelum dilakukan penyuluhan diukur pada soal pretest nomor 5. Hasil nilai pretest peserta pada pertanyaan nomor 5 tentang tanaman berpotensi sebagai pendamping terapi kanker serviks 
masih rendah yaitu sebesar 52\% (gambar 7). Setelah dilakukan penyuluhan, pengetahuan peserta tentang tanaman yang berpotensi untuk pendukung terapi kanker serviks meningkat. Hal ini ditunjukkan dengan adanya peningkatan nilai peserta pada soal posttest nomor 5 yaitu menjadi $100 \%$ (gambar 7).

Gambar 7. Persentase hasil pretest dan postest nomor 5 tentang tanaman yang bermanfaat untuk terapi kanker serviks

\begin{tabular}{|c|c|}
\hline $\begin{array}{l}\text { Persentase jawaban benar pada } \\
\text { soal pretest no.5 }\end{array}$ & $\begin{array}{l}\text { Persentase jawaban benar pada soal } \\
\text { posttest no.5 }\end{array}$ \\
\hline $\begin{array}{l}48 \% \\
\end{array}$ & $100 \%$ \\
\hline
\end{tabular}

Secara keseluruhan, pengetahuan peserta tentang kanker serviks dan terapi pendukungnya secara alami dapat dikatakan meningkat setelah dilakukan kegiatan penyuluhan. Hal ini ditunjukkan dengan adanya peningkatan nilai rata-rata pretest seluruhnya yang semula 60,8 menjadi 96,2 pada saat posttest (gambar 8). Peningkatan tingkat pemahaman Ibu-ibu PKK Desa Laban tentang kanker serviks dan terapi pendukungnya secara alami mencapai 30\%. Hal ini juga merupakan salah satu indikator tingkat keberhasilan dari kegiatan dan program yang telah dilakukan .

\section{Gambar 8. Grafik perbandingan nilai pretest dan postest peserta}

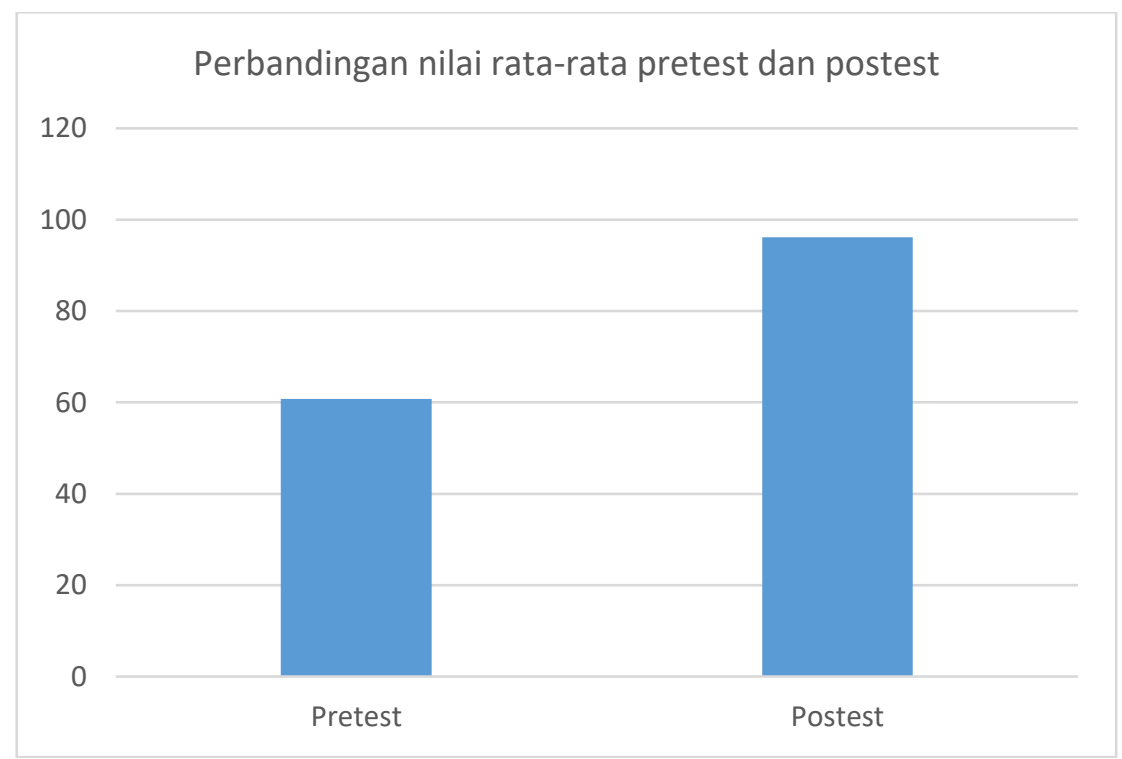


Workshop pembuatan minuman segar herbal berbahan daun sirsak, bunga rosella dan madu juga berhasil. Keberhasilan workshop ini dilihat dari peningkatan keterampilan ibu-ibu PKK Desa Laban yaitu dari semula belum dapat menjadi dapat membuat produk "ROMANSA". Bahkan ibu-ibu PKK Desa Laban berminat untuk memproduksi dan memasarkannya. Dalam workhop ini juga diberikan informasi cara pengajuan ijin edar P-IRT jika akan memasarkan produknya.

Evaluasi kepuasan peserta terhadap kegiatan program pengabdian masyarakat ini diukur dengan pengisian kuesioner kepuasan pelaksanaan kegiatan oleh sebagian peserta, yaitu 40 peserta yang disampling secara acak. Hasil pengisian kuesioner menunjukkan bahwa tingkat kepuasan peserta pengabdian masyarakat secara keseluruhan $>50 \%$ dari total 40 responden menyatakan baik sekali (gambar
9). Berdasarkan pengisian kuesioner tersebut, kepuasan peserta terhadap materi yang disajikan, respon masyarakat terhadap program, keterkaitan materi dengan kebutuhan masyarakat, keterkaitan materi dengan aplikasi yang dapat diterapkan di masyarakat, pemateri dan teknik penyajian, waktu yang dipergunakan dalam pemberian materi, kejelasan materi, minat masyarakat, serta kepuasan kegiatan lebih banyak dinilai baik oleh peserta, sisanya menilai baik. Peserta program pengabdian masyarakat yakni ibu-ibu PKK Desa Laban pun menyampaikan harapan supaya Sekolah Tinggi Ilmu Kesehatan Nasional terus melanjutkan kerjasama dengan Desa Laban untuk memberikan edukasi tentang kesehatan terkait tema lainnya. Para peserta berharap dengan keberlanjutan kegiatan tersebut pengetahuan masyarakat Desa Laban tentang kesehatan terus meningkat.

Gambar 9. Grafik hasil evaluasi kepuasan peserta terhadap program pengabdian masyarakat

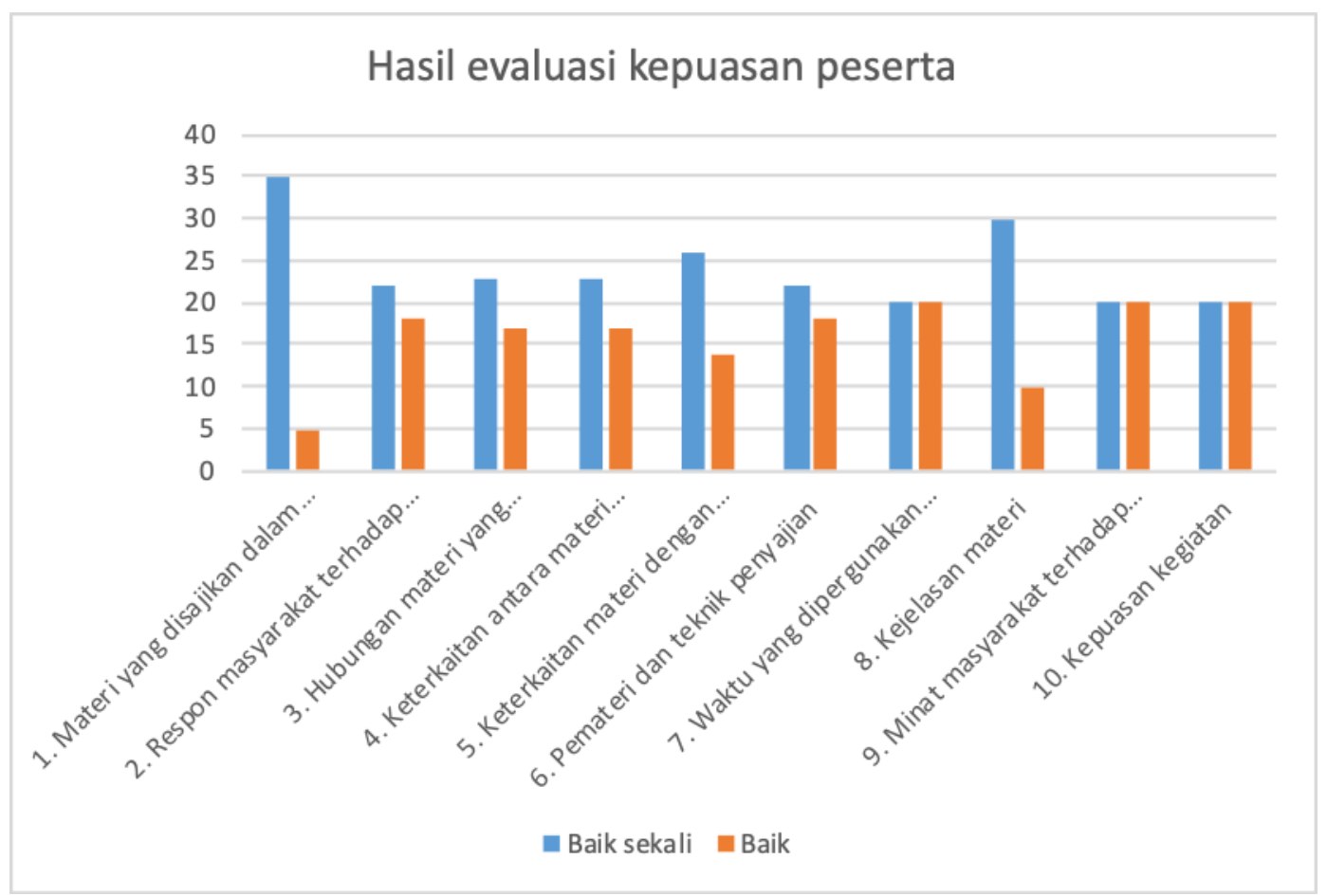




\section{Gambar 10. Foto bersama dengan Tim Pembina PKK Desa Laban, Mojolaban, Sukoharjo (Dokumentasi Pribadi)}

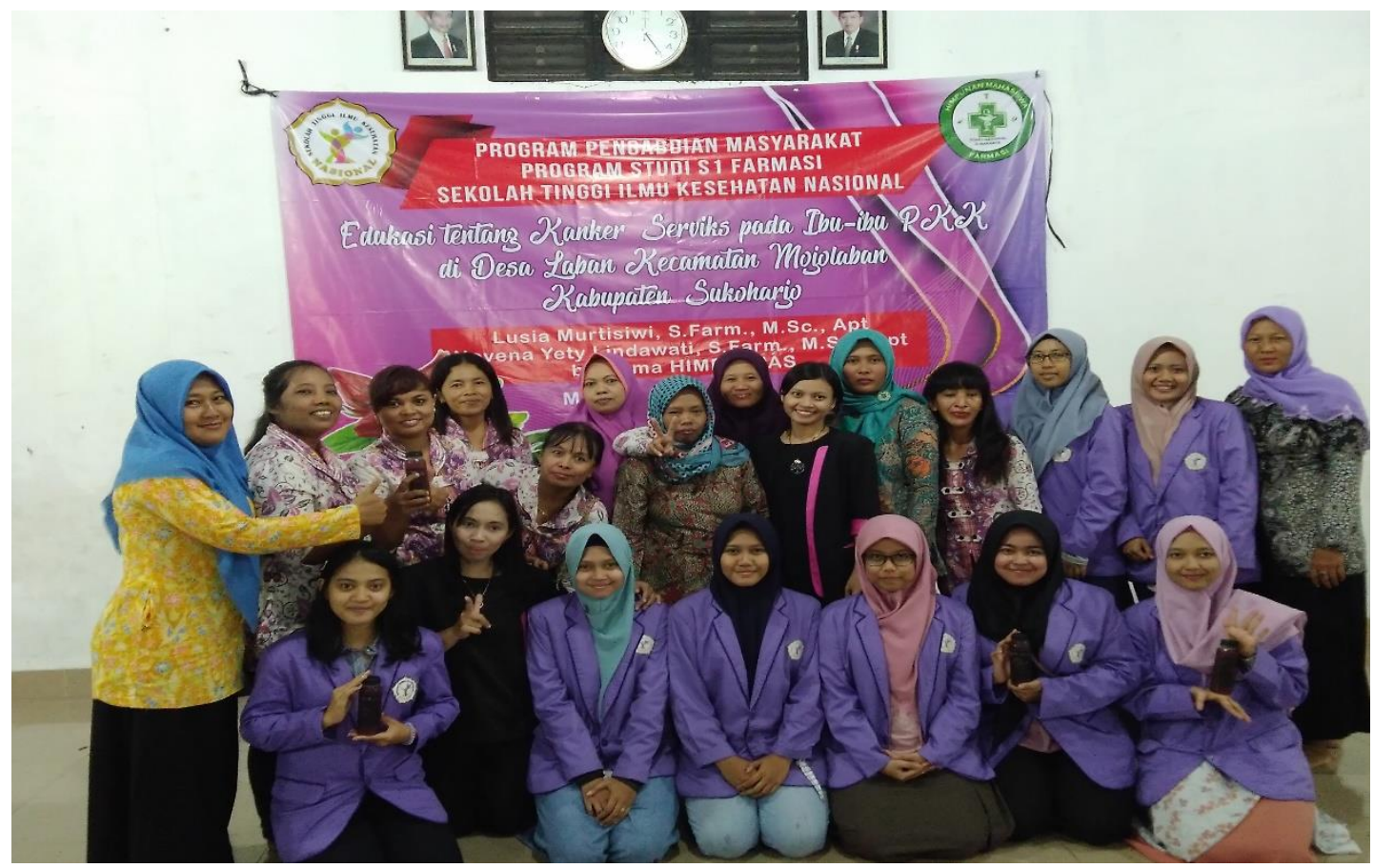

\section{KESIMPULAN}

Kegiatan pengabdian masyarakat tim STIKES Nasional Surakarta bekerjasama dengan PKK Desa Laban, Kecamatan Mojolaban, Kabupaten Sukoharjo dapat meningkatkan pengetahuan dan wawasan masyarakat Desa tentang upaya preventif, promotif, kuratif, dan rehabilitatif terhadap deteksi dini kanker serviks serta meningkatkan pengetahuan dan wawasan masyarakat tentang terapi alternatif alami pendukung penanganan kanker serviks serta perubahan gaya hidup

\section{DAFTAR PUSTAKA}

American Cancer Society, (2010). Cervical Cancer.

http://www.cancer.org/acs/groups $\angle$ cid/documents/webcontent/0030 94-pdf.pdf
Diananda, R., (2009). Panduan Lengkap Mengenal Kanker, Mirza Media Pustaka, Yogyakarta.

Kemenkes RI, (2015). Situasi Penyakit Kanker. Retrieved Oktober 12, 2018. https://www.depkes.go.id , download , pusdatin , buletin , buletin-kanker

WHO, (2018). Cervical Cancer. Retrieved Oktober 12, 2018, from http://www.who.int/cancer/preve ntion/diagnosis-screening/cervicalcancer/en/. 